\title{
Health policy in interwar Greece: the intervention by the League of Nations Health Organisation
}

\author{
Vassiliki Theodorou (*) and Despina Karakatsani (**) \\ $\left(^{*}\right)$ Department of Primary Education, Democritus University of Thrace. vtheodor@eled.duth.gr \\ ${ }^{* *}$ Department of Social and Educational Policy, University of Peloponnese.
}

Dynamis

[0211-9536] 2008; 28: 53-75
Fecha de recepción: 1 de septiembre de 2006

Fecha de aceptación: 26 de febrero de 2007

SUMMARY: 1.-Concerns about public health after World War I. 2.- Refugee settlement and the appeal to the international community. 3.-The appeal to the League of Nations. 4.-The L.N.H.O. plan. 4.1.-The first reactions. 5.-The involvement of the Rockefeller Foundation and the campaign against malaria. 6.- The accomplishments of the involvement of international health organisations. 7.-Concluding remarks: what caused the plan to fail.

ABSTRACT: The first serious attempts to deal with public health problems in Greece were undertaken between 1925 and 1935. This period also witnessed setbacks to developments in public health, caused by the lack of welfare infrastructure for social relief, as well as extensive health problems brought about by the settlement in Greece of 1,300,000 refugees from Asia Minor. In 1928 following the example set by other European countries, the Liberal Government appealed to international health organisations for support in order to effectively deal with these problems. This contribution constitutes a case study addressing the following issues: a) the impact the League of Nations Health Organisation intervention had on the establishment of public health services; b) the framework for a collaboration of the Rockefeller Foundation and the League of Nations Health Organisation; and c) the factors that led to the failure of the health care reorganisation.

PALABRAS CLAVE: Salud pública, Grecia, Organización de Higiene de la Sociedad de Naciones, Fundación Rockefeller, campos de refugiados.

KEYWORDS: Public health, Greece, League of Nations Health Organisation, Rockefeller Foundation, refugee settlement.

In the aftermath of World War I, certain European governments sought the support of international health organisations in order to counteract health problems brought about by population movement, an increase in the number of refugees and the spread of transmissible diseases. During the Interwar period, the issue of public health came to the fore for national 
politics and international collaboration; the latter was considered a decisive factor in establishing an international network of health experts who would follow common patterns of health administration ${ }^{1}$. The 1920 s witnessed the involvement of international organisations and charitable foundations such as the League of Nations Health Organisation (henceforward L.N.H.O.) and the Rockefeller Foundation (henceforward R.F.) in Central and Southern European countries; their involvement was designed not only to lend their expertise to the organisation of public health services but also to fund health programmes. Moreover, this involvement also made possible the worldwide development of public health science, which took into consideration both the epidemic and socio-economic factors that caused illness. This development coincided with the reconstruction of clinical medicine through social science ${ }^{2}$ : social work and health work were combined under the direction of efficient health experts who adopted American methods of organisation.

The methods employed by international organisations in order to modernise health care and create a professional elite of biomedical and medical experts paved the way for the establishment of this «new science of public health» ${ }^{3}$. Schools of Public Health were established, using the Baltimore School of Public Health as a model; field research was carried out; fellowships were provided for public health officers to attend American universities; preventive medicine gained a firmer foothold; epidemiological data were collected and classified; but the major step undertaken was to educate the population: all these constituted common goals pursued by the heads of international health organisations and adopted by the majority of European countries after the end of World War I ${ }^{4}$. The aim of these health organisations was to establish rational and homogeneous methods and means of scientific approach; however, in each instance, local bureaucracy;

1. Weindling, Paul, ed. International health organisations and movements 1918-1939. Cambridge: Cambridge University Press; 1995; Rodriguez-Ocaña, Esteban, ed. The politics of the healthy life. An international perspective. Sheffield: EAHMH Publications; 2002.

2. Weindling, Paul. Social medicine and the League of Nations Health Organisation and the International Labour Office compared. In: Weindling, n. 1, p. 134-153.

3. Löwy, Ilana; Zylberman, Patrick. Medicine as a social instrument: Rockefeller Foundation, 19131945. Studies in History and Philosophy of Biology and Biomedical Sciences. 2000; 31 (3): 365-378.

4. Löwy; Zylberman, n. 3 and other articles by Balinska, Rodríguez-Ocaña and Pallo at the same monographic issue of Studies in History and Philosophy of Biology and Biomedical Sciences. 
the extent of collaboration between national and international elites, the conjuncture of political and economic events, and the role of leading local medical figures and politicians were factors that had a serious impact on how reform plans were implemented.

This paper explores the attempt to reform the health care system in Interwar Greece and the background of the collaboration between national and international health organisations. Compared to Central and SouthEastern European countries, Greece was not successful in taking advantage of the L.N.H.O. involvement to develop a public health policy ${ }^{5}$, even though conditions in the country were horrendous, due to severe epidemics caused by the influx of refugees from Asia Minor in 1922. We seek to address how and why the Greek case diverges from the common pattern in the context of the European history of public health policy. We are interested in exploring events and currents behind the appeal to the League of Nations; as well as the factors that rendered the attempt to restructure the Greek public health system a failure. Additionally, we describe the collaboration between state agencies, charitable societies and international organisations, as well as the difficulties posed by public health bureaucracy.

\section{Concerns about public health after World War I}

For more than 70 years after the founding of the Greek state (1830) the country's health care system was primarily based on charity, on military medical services, and on a few municipal hospitals such as those at Ermoupolis and Athens ${ }^{6}$. Typhus, diphtheria and smallpox epidemics frequently swept the country and morbidity rates for malaria and tuberculosis remained high until 1930.

From the early 20th century a group of physicians attempted to define the health problems within social and economic discourse, while protesting

5. Borowy, Iris; Gruner, Wolf, eds. Facing illness in troubled times. Health in Europe in the interwar years, 1918-1939. Berlin: Peter Lang Verlag; 2005; Weindling, n.1. Weindling, Paul. Public health and political stabilisation: The Rockefeller Foundation in Central and Southeast Europe between the two world wars. Minerva. 1993; 3: 253-267; Balinska, Martha A. The National Institute of Hygiene and Public Health in Poland 1918-1939. Social History of Medicine. 1996; 3: 427-445.

6. For a list of Hygiene services from the establishment of the Greek State up to 1933, see Makridis, Nikolaos. Hygiene services in Greece (in Greek), Athens; 1933. 
about the absence of public health statistics and the lack of a public health system. In their view, state indifference was to blame for all these inadequacies that put Greece «at the bottom of the scale for civilized countries» ${ }^{7}$. The anti-tuberculosis Society and the anti-malaria Society, both set up at the start of the 20th century, serve as typical examples of the answers to such criticisms carried out by various charitable societies, established by a medical authority ${ }^{8}$. These active hygienists, educated abroad, mostly in Paris and Vienna, usually worked as medical officers and tried to convince the wealthy Greek Diaspora to fund TB dispensaries, sanatoria or other institutions for the relief of indigent patients. Moreover, they attempted to educate people by explaining sanitation in simple terms to the public and convincing politicians to provide against contagious diseases and take action in order to strengthen those susceptible to diseases, particularly children.

The prolonged period of war, including the Balkan Wars (1912-1913), World War I and the Asia Minor military campaign (1920-1922), had serious repercussions for Greece, bringing with it continuous waves of population migrations, which exacerbated the aforementioned problems, while the country was assuming new responsibilities due to its territorial expansion. The latter, in conjunction with the call to build a healthy nation formed a new basis for public health considerations ${ }^{9}$. Moreover, repeated mobilisations of the country's male population from 1912 to 1922 revealed a large number of physically disabled individuals, thus making the citizens' physical and mental health a priority issue ${ }^{10}$.

The Liberal Government that dominated the country's political life in the 1920s committed itself to restructuring the public health system in the context of establishing a welfare state. The parliamentary debate on the establishing a Health and Social Welfare Ministry began in 1921 and it was the first serious attempt to map out the organisation of the country's

\footnotetext{
7. Patrikios, Vassilis. Tuberculosis in Greece (in Greek), Athens; 1903, p. 35

8. Theodorou, Vassiliki. Doctors' attitude towards the social issue. The struggle against tuberculosis at the beginning of the 20th century (1901-1926) (in Greek). Mnimon. 2002; 24: 145-178.

9. Borowy; Gruner, n. 5, p. 12. On eugenics and puericulture see Theodorou, Vassiliki; Karakatsani, Despina. Eugenics and puericulture in Interwar Greece: medical concerns regarding the amelioration of the biological capital. Paper presented at the International Conference: Hygiene-Health politics-eugenics: engineering society in twentieth-century Southeastern Europe, Freie Universität Berlin, 31 May-2 June 2007.

10. Liakos, Antonis. Labour and politics in interwar Greece. The International Labour Office and the emergence of social institutions (in Greek). Athens: Research and education Foundation of the Commercial Bank of Greece; 1993, p. 314-335.
} 
health services ${ }^{11}$. Two health officers, Konstantinos Savvas (1861-1929), professor of Hygiene at the University of Athens and Emmanuel Lambadarios (1885-1942), head of the School Medical Service, were assigned the task of drawing up the corresponding Bill. Both were ardent supporters of a serious public health policy and were in regular contact with international health organisations. Once the Bill passed, despite strong opposition by the Medical Association, social hygiene institutions for the protection of childhood and the reduction of infant mortality were planned for the very first time in Greece. The new law also provided for the establishment of health services to combat tuberculosis, malaria and venereal disease, public health statistics and publication services. Regulations for urban hygiene and food inspection were introduced, and measures were taken to improve workingclass housing and modern social welfare institutions were adopted.

\section{Refugee settlement and the appeal to the international community}

However, because Greece received 1,300,000 refugees from Asia Minor only a few months after this bill was passed, the new law was pigeonholed and never came into effect. Soon after World War I, the Greek military campaign on the Asia Minor front (1920-1922) ended in failure and led to the Treaty of Lausanne (July 1923), which dictated that all Christian inhabitants of Greek origin, living in the Eastern Thrace and Asia Minor, had to re-settle in Greece. The settlement of these refugees brought about an unprecedented increase in the country's population over a few months and entailed economic, social and public health upheavals. These problems appeared insurmountable for a small country such as Greece, which lacked public health infrastructure and, as a result, the country found itself in a critical situation for about a decade. The high rates of mortality among the refugees testify to the poor conditions in which they were moved, settled and lived ${ }^{12}$. During the following years, Greek and foreign philanthropic organisations, such as the American Near East Relief (henceforth A.N.E.R.),

11. The Ministry of Health underwent numerous changes with regard to its name during the 1920s and 1930s.

12. Katsapis, Kostas. Public health, refugees and state intervention in interwar Greece. In: Beyond the Asia Minor disaster. Asia Minor refugees in interwar Greece. Athens: Foundation of Hellenic World (in Greek); 2003, p. 41-73. 
the American Red Cross and the Save The Children Fund, attempted to make up for deficiencies in the public health infrastructure in the refugee settlements.

Shortly after September 1922, typhus, dysentery and smallpox epidemics spread and claimed the lives of many refugees; meanwhile, a considerable number of deaths had already occurred due to the severe conditions faced by refugees in transit. Contagious diseases decimated refugees and poor housing conditions and inadequate water supply made the situation even worse $^{13}$. Despite aid offered in 1923 by the Epidemic Commission of the League of Nations and by other countries to relieve the situation, malnutrition and poor living conditions remained the main reasons for contracting malaria, which affected $95 \%$ of the refugees settled in the swampy plains of Macedonia and Thrace. The fact that Greece imported $1 / 4$ of the world quinine production is illustrative of the country's plight. In 1923, malaria accounted for $70 \%$ of deaths occurring among those settled in the Northern Greek rural areas ${ }^{14}$.

Between 1924 and 1931 hundreds of refugee settlements were built across the country by the Refugee Settlement Commission (1924) (henceforward R.S.C.), formed with the support of the League of Nations, mainly in rural areas; yet the residential problem was still not addressed effectively for many, particularly for those settled in shacks on the fringes of urban centres ${ }^{15}$. Water supply, sewerage problems and poor sanitary facilities resulted in dysentery and typhus epidemics, which frequently broke out in these areas until 1928. In addition, high mortality rates due to tuberculosis led many people to characterise the refugee settlements as «tuberculosis towns». Accommodation in poorly built houses, deficient nutrition and hard work, lack of basic sanitation rules and inadequate health care infrastructure - only 4 TB dispensaries were established before 1920- attracted the interest of physicians who attempted to address the problem of tuberculosis and drew a connection between the poor living conditions of refugees and the possibility of sickness.

13. Kopanaris, Phokion. Public health in Greece (in Greek). Athens: 1933, p. 40 and 47.

14. Kardamatis, loannis. Education on fighting malaria in Greece. Action in Macedonia and Thrace, (in Greek). Athens: Greek Red Cross; undated.

15. Leontidou, Lila. Cities of silence. Working-class settlement of Athens and Piraeus 1909-1940 (in Greek). Athens: 1989; Pentzopoulos, Dimitris. The Balkan exchange of minorities and its impact upon Greece. Paris: 1960. 
The Ministry of Health and Social Welfare, which was finally established a few months after the arrival of the refugees (November 1922), attempted to accommodate the country's pressing healthcare needs by setting up new hospitals in Central and Northern Greece, for the sole purpose of caring for refugee patients, and by establishing public rural dispensaries. However, these hospitals were endowed with an insufficient number of beds, and the public dispensaries, mostly located within refugee camps and run by refugee doctors, also failed to fulfil their purpose because they lacked adequately trained personnel and collaboration by the patients' relatives. Finally, measures concerning the compulsory registration of cases of contagious diseases by doctors, as well as by the patients themselves, did not have the intended results.

At the same time, in the mid 1920s, the R.S.C. attempted to set up a health organisation system intended for the rural population of Macedonia and Thrace which would operate in parallel with that administered by the Health and Social Welfare Ministry ${ }^{16}$. The idea was that one or more villages would jointly employ a doctor who was to be paid only by the resident families in return for his exclusive services. The initial plan provided for each refugee village to have its own rural dispensary serving somewhere between 500 to 800 refugee families. Inhabitants would pay a small amount of money for the provision of full medical care whereas under certain terms and conditions underprivileged members of each community could also benefit from the same services. The above model was a rather complete proposal since it provided not only for the refugees' medical but also for their pharmaceutical care. The first 53 dispensaries, which began operating in 1925, would serve as a starting point for the expansion of the system to the whole country. In April 1929, a few months before the Commission's withdrawal from Northern Greece, according to the list provided by Charles Eddy, chairman of the R.S.C., there were about 60 dispensaries operating in rural refugee settlements which dealt with serious public health problems ${ }^{17}$.

Besides the R.S.C., the Near East Relief, an American voluntary organisation, was active in the same areas, offering services for the relief of orphans and providing health care for the rural population, particularly in

16. Doxiadis, Apostolos. La question des réfugiés en Grèce. Paris: 1924.

17. Letter from Eddy to Doxiadis, 22 April 1929, Doxiadis Papers, 256, folder 9, Historical Archives, Benaki Museum, Athens. 
Macedonia ${ }^{18}$. In 1929 it was renamed, becoming the Near East Foundation (henceforth N.E.F.), and turned into an educational organisation. By adopting American methods, the N.E.F. favoured agricultural development and the establishment of public health demonstration stations in rural areas with poor health and sanitary conditions. The most systematic attempt in that direction was the «Macedonian Village Extension Programme»; forty-eight villages located throughout a wide area of Macedonia were selected for the demonstration. The aim was to instil in rural populations an understanding of the fundamental rules of hygiene and sanitation, as well as to adopt better methods of cultivation.

Both the doctors at R.S.C. rural dispensaries and the N.E.F. technical staff introduced American methods for improving public health. Their work, studying climate conditions and the water supply and sewerage systems, collecting data about malaria and the mosquito control campaign, formed the basis for the application of the L.N.H.O. programme.

\section{The appeal to the League of Nations}

In order to deal effectively with health problems, the Greek Government resorted to the League of Nations for help. In 1923, two members of the Epidemic Commission took on the preventive vaccination of refugees and the organisation of sanitary facilities in refugee settlements ${ }^{19}$. In addition, experts were often seconded to Greece to advise the Greek Government on health initiatives to be taken in areas inhabited by refugees. Furthermore, the Liberal Government turned to the League of Nations for monetary assistance, whereas since 1920 there was collaboration with the International Labour Organisation in order to establish a social insurance system.

18. Starting in 1919, N.E.R. was active in Greece attending to the needs of the refugee orphans. After 1922 its contribution became more important. Barton, James. Story of Near East Relief 1925-1930. An interpretation. New York: The Macmillan Company; 1930. Badeau, John; Stevens, Georgiana, eds. Bread from stones: fifty years of technical assistance. New Jersey: Prentice-Hall Inc.; 1956.

19. From November 1922 to April 1923, 550,000 refugees were vaccinated against cholera, malaria, and typhus thanks to a donation by Nansen who was high Commissioner for refugees of the League of Nations. L'Organisation d'Hygiène de la Société des Nations. Geneva, 1923, p. 26-28; Balinska, Martha Alexandra. Assistance and not mere relief: the Epidemic Commission of the League of Nations, 1920-1923. In: Weindling, n. 1, p. 81-108. Doxiadis Papers, folder 4, 1923. 
The decision to request more substantial help from the League of $\mathrm{Na}$ tions seemed more urgent than ever before when an epidemic of dengue fever swept through Greece at the beginning of $1928^{20}$, affecting 1,320,000 people from October 1927 to July 1928, and bringing the country's economy to a standstill. During the epidemic, the Health Committee placed one of its members at the government's disposal; this collaboration was quite promising. In October 1928, the Liberal Government, and more specifically the Under-Secretary for Hygiene, Apostolos Doxiadis (1874-1942), suggested seeking the assistance of the L.N.H.O. with a view to reorganising the country's health services, following the advice of M.D. Mackenzie, an R.S.C. advisor and member of the Health Section of the League Secretariat. Doxiadis was probably the most suitable person to support such a proposal: having studied medicine in Vienna, Berlin and Paris at the end of the 19th century, he was an eminent doctor in Greece, and an ardent supporter of social medicine. In his capacity as Welfare Minister from 1922 to 1924, a crucial period following the settlement of the refugees, he collaborated with foreign charity organisations and drew up the memorandum which the Greek government presented to the League of Nations in 1923 in order to ensure financial assistance for the refugees' settlement.

The letters exchanged between Doxiadis and Mackenzie point to the fact that both Mackenzie and Ludwik Rajchman, medical director of the Health Section, used their influence with the Health Committee so the League of Nations would accept the request of the Greek government. Mackenzie made it clear that the League of Nations intended to support the Greek government on two levels; first, to make scholarships available to public health officers, statistics officials and hygiene engineers, and offer its advice on the legislative revision of public health. Second, Mackenzie implied that the League of Nations would do whatever it took to secure the financial aid of the Health Division of the R.F. ${ }^{21}$.

The Greek request was approved by the League of Nations Council in the 13th of December 1928 session presided by M. Briand. Quiñones de Leon, advocate at the League of Nations, related the above appeal to the country's financial restructuring ${ }^{22}$. Public health constituted a determining

20. Makridis, Nicolaos. The dengue epidemic in Athens (1927-1928) (in Greek) Athens: 1928.

21. Mackenzie to Doxiadis. September 15, 1928, Doxiadis, Papers, 256, folder 11.

22. Société des Nations, Cinquante-troisième session du conseil, sujet: Réorganisation de l'hygiène 
factor in the country's economic recovery and, as such, was central to the Liberal Party programme. The fact that the newly elected government undertook a really ambitious programme of internal reconstruction rendered the reorganisation of public health imperative. During the election campaign, Venizelos had promised to undertake public health reconstruction - one of a number of campaign pledges. As Doxiadis argued on December 13, 1928, in the speech he delivered in Geneva, in his capacity as the government representative to the Council session ${ }^{23}$, the political and economic stability of the country at present guaranteed the success of the attempt; in addition, the extensive public works the government had already under way constituted an ambitious project to counteract malaria. The Council requested the Health Committee: «to place at the disposition of the Hellenic Government all its technical means, including its technical commissions in such a manner as would provide its full collaboration to the preparation as well as the later development to the plan at which it would arrive» ${ }^{24}$.

In early 1929, the League of Nations Health Section formed a research group of seven health experts, headed by Ludwik Rajchman ${ }^{25}$. The rest of the committee members were Haven Emerson, professor at the University of Columbia, Allen McLaughlin of the U.S.A. Health Organisation, C.L. Park of the Australia Public Health Organisation, B. Borcic, head of the Zagreb School of Hygiene and M.D. Mackenzie, a hygienist at the League of Nations. They arrived in Greece on the 25th of January 1925 to carry out a four-month field survey in 3 major cities, 14 towns and 82 villages in Northern Greece (Macedonia, Thrace and Giannena); the metropolitan region of Athens and Piraeus; Crete and Corfu. These areas were studied in terms of economic resources, demographic profile, medical services and sanitary conditions.

Their field research lasted until April 9, 1929. On that same day, the chairman and the vice-chairman of the Health Committee, Léon Bernard and George Buchanan, and the chairman of the Malaria Commission arrived in Athens in order to offer their advice to the Greek Health Commit-

publique en Grèce: Requête de Gouvernement grec relative à une collaboration du Comité d' hygiène de la Société, C/53me session/P.V.4(I), Doxiadis, Papers, 256, folder 11.

23. The Prime Minister E. Venizelos asked A. Doxiadis to represent the government before the League of Nations. See Karapanos (Minister of Foreign Affairs) to Doxiadis, November 21, 1928, Doxiadis Papers, 256, folder 12.

24. Société des Nations, n. 22, p. 2.

25. Liakos, n. 10, p. 326. 
tee. Once the research was complete and reports had been submitted, the Geneva Health Committee, accompanied by Gustavo Pittaluga, Professor of Parasitology at the University of Madrid and member of the Malaria Commission of the League of Nations, arrived in Greece on April 11th to conduct further research on malaria problems. After meeting with Greek government officials and visiting Macedonia, the committee submitted its final proposal to the Greek government on April 18th.

\section{The L.N.H.O. plan}

The Committee of health experts recorded their observations in 148 reports which also reflected their amazement at the low standards of health services. In their introduction to the plan, the experts argued that the situation was so alarming that the need to adopt hygiene measures in Greece was pressing; they stressed that they had no intention of comparing Greece to other European countries, yet in private discussions they pointed out that «as far as hygiene is concerned, Greece is a dangerous country». Epidemic and endemic diseases combined with the lack of hygiene measures were indicative of the situation: «Let it suffice to say that we had strong evidence that malaria, tuberculosis, typhoid fever and dysentery are widely spread, the protection of motherhood and children is susceptible to further improvement and the patients' treatment is conducted under poor conditions» ${ }^{26}$. On inspection, most hospitals were found to be badly built «and packed with patients to such an extent that it was impossible to offer them the minimum of treatment necessary for their recovery» ${ }^{27}$. They also underlined that «such a lack of health services and social welfare was not encountered even in countries of the lowest cultural standard ${ }^{28}$.

The plan for the country's reorganisation put forward by the Geneva experts was modelled on the health systems of Central and Northern European countries. It emphasised the establishment of a public health

\footnotetext{
26. League of Nations Health Organisation: Collaboration with the Greek government in the sanitary reorganisation of Greece. Geneva, May 1929, (Official N.C. 162.M.63 1929 III), p. 4, see Doxiadis Papers, folder 12

27. League of Nations, n. 26, p. 5.

28. See the private discussion of Rajchman with the British delegate in Geneva. Liakos, n. 10, p. 328.
} 
service, training for health staff and the teaching of hygiene. Since prevention was totally absent in Greece, preparation for public health staff was very important to the country's health reorganisation. Reorganisation focused primarily on the eradication of malaria and tuberculosis, and the protection of childhood. Besides, the plan highlighted that success of the measures would depend on the establishment of public welfare services such as public water-supply, drainage, lighting, town planning, construction of healthy houses and schools, and recreation and athletics grounds. Although experts emphasised the fact that the Liberal government had undertaken extensive public works for rural sanitation, they did not omit to allude to the indifference of municipal and prefectural authorities to «such amenities».

Their final proposal provided for the establishment of the Greek Health Service, a central organisation that would coordinate all public and private health services. It would be directly subject to the Prime Minister and assisted by a board consisting of Health Division directors. Hygiene matters throughout the country would fall within its jurisdiction and the Health Service would reserve the right to intervene in emergency situations. The Health Service would be staffed by experts and thus would lay the foundations of Preventive and Social Medicine in Greece. The establishment of the School of Hygiene in Athens would fill the existing void in the training of hygienists, public health officers and visiting nurses, and the operation of Health Centres across the country would make decentralisation of the health services possible. The plan allowed for a transition period of three to four years; during that time all health services of various ministries would come under the jurisdiction of the Under-Secretariat of Health.

After this transition period the School of Hygiene and the central technical services would form the Athens Centre comprising: a) The Division of Malariology; b) the Division of Hygiene and Preventive Medicine; c) the Division of Hygiene Engineering; d) the Division of Pharmacology and Biochemistry; and e) the Division of Research. Each division would carry out research, compile statistics, and plan campaigns to counteract problems falling within its jurisdiction. Great emphasis was placed upon field research and laboratory tests. Each division would be directed by an eminent medical doctor who would undertake to train the School of Hygiene medical personnel. Experts underscored the importance of the qualifications of doctors and officials of the central service; it was evident that they wanted to train the public health officials who would later man health services. 
The pilot programme would be initially applied to areas where experts had carried out research (Athens, Piraeus, Salonica, Giannena, Chania, Corfu and Macedonia). Its aim was to create a network of health centres in each area, covering three to five health centres. The Health Centre was the core of the proposed Health Care System. Each Centre would include one or more dispensaries for malaria, tuberculosis and children's diseases (paediatric clinics were to be established in cities), groups of visiting doctors, hygiene inspectors, a pharmacy, public baths as well as recreational and educational facilities. In an attempt to prompt a more general participation by Greek society in public health policy, the League of Nations suggested the creation of a consultative body consisting of academics and representatives of the working classes, workers' unions, army, church, primary and secondary education teachers, local authorities, doctors and journalists. Great emphasis would be put on two centres: the Salonica centre and the Metropolitan Athens-Piraeus centre. The latter would be responsible for conducting tests on food and drinking water as well as statistic and demographic studies, and supervising factories.

L.N.H.O. health experts stressed the modernisation of community life. According to their reports, the success of the health system reform depended on improving social welfare measures. Emphasis was also placed on the medical profession; the plethora of doctors in the cities as well as their inadequate education and training, especially as far as preventive medicine was concerned, were pointed out. Nurses were also described as unqualified and their profession as lacking prestige.

The Committee of experts estimated the operational cost of the health services up to 1935; by this time this new scheme was scheduled to become fully operational after five years of systematic preparation. Twenty-five million Greek drachmas was the rough estimate for the first year of operation, while for the year 1935 the operational cost would reach 75 million Greek drachmas. Since no buildings were available, the Committee suggested the School be accommodated temporarily in prefabricated premises in order to commence operations.

\subsection{The first reactions}

The proposal of the League of Nations experts bore many similarities with the memorandum Doxiadis himself had submitted to the government a 
few weeks after assuming responsibility as Under-Secretary for Hygiene ${ }^{29}$. According to his own testimony, the memorandum was submitted to the L.N.H.O. and was taken into consideration by the hygienists who tailored the final proposal. However, identifying the Doxiadis proposal as the reform plan put forward by the Committee remains only a hypothesis.

Although Doxiadis favoured this type of reform, he had certain reservations as far as the implementation of the plan was concerned. In correspondence exchanged between the members of the Greek government, Doxiadis and Venizelos, and the Health Committee members, mainly Rajchman and Madsen, the president of the L.N.H.O., between April and May 1929, signs of disagreement can be detected.

Their disagreement mainly concerned funding; the structure of the new health services, and the way the latter would be staffed. Rajchman suggested that all public health responsibilities be placed under the authority of the central health service and all health divisions operating in various ministries come under its jurisdiction. Administrative unity was considered to be a prerequisite for the programme's success ${ }^{30}$; expertise, namely staffing health services with skilled public health administrators, was crucial to the programme's successful completion. The idea of forming an elite of health professionals with high salaries aroused controversy not only with politicians but also with the medical corps. The Polish director of the Health Committee insisted that the staff hired be highly skilled in the public health field and work exclusively as such. Rajchman demanded that doctors selected to pursue further training abroad should take it for granted that upon their return to Greece they would be employed exclusively in high-ranking posts and as a consequence they would have to set aside their private practice. Moreover, the director of the Health Committee drew the attention of Greek politicians to the necessity of staffing health services with experts on the basis of their skills, in other words to avoid political appointments.

A few days after the proposal's submission, Doxiadis criticised the Committee's plan ${ }^{31}$. Pleading a better understanding of the Greek civil servant mentality and economic reasons, he argued that the central service should be manned not with newly appointed officers but with civil serv-

\footnotetext{
29. Les services d' hygiène en Grèce. Memorandum. Doxiadis Papers, 256, folder 11.

30. Rajchman to Doxiadis, 15 May 1929, Doxiadis Papers, folder 11.

31. Doxiadis to Venizelos, 25 April 1929, Doxiadis Papers, folder 9.
} 
ants transferred from other services. However, these officials would not come under the administration of the health centre; they would be partly employed in the health centre as far as the organisation of social hygiene was concerned, but they would still form part of the administration of the regional services to which they initially belonged. Doxiadis was worried that placing all health services, which were dispersed in various ministries, under the supervision of the central service of the Under-Secretariat would instigate tension amongst officials and make a bad impression on public opinion. Cutting costs was one of the arguments he resorted to in order to persuade Venizelos to raise objections to the Geneva Committee. In addition, Doxiadis argued that the R.S.C. dispensaries were not suitable for preventive medicine, whereas Rajchman claimed that after minor alterations, these dispensaries could be turned into health centres, since their network was by far the better organised compared to all other dispensaries visited by the L.N.H.O. members ${ }^{32}$.

This disagreement led to misunderstandings between the two interested parties ${ }^{33}$. The objections raised by Greek politicians were presented to the Health Committee, discussed but, in the end, turned down. Rajchman and Thorvald Madsen informed the Greek government that if administrative unity was not maintained, the reorganisation plan would be deemed to failure $^{34}$. In the end, on May 7, the proposal was accepted by the Health Committee but the Greek government's objections were not taken into account. This concluded the first round of collaboration between the government and the L.N.H.O. Venizelos thanked the Committee members, underlining the fact that the Committee's technical support was expected in order to implement the programme ${ }^{35}$.

32. Agnides to Doxiadis, Geneva, 8 May 1929, Doxiadis Papers, folder 11.

33. Rajchman's reaction to the changes put forward by Doxiadis in a letter addressed to the latter by Agnides, official at the League's General Secretariat, May 4, 1929, Geneva, Doxiadis Papers, folder 11: «ll m'a même dit que les idées y énoncées étaient de nature à rendre inopérants le plan et les recommandations de la mission sanitaire».

34. Madsen to Raphael, Geneva, May 7, 1929. Doxiadis Papers, folder 11. Raphael was chargé d' affaires of the Greek government in Geneva.

35. Venizelos to Madsen, April 19, 1929, Doxiadis Papers, folder 11. Rajchman assured Doxiadis that he would support the government as far as the programme's implementation was concerned. Besides, it was Rajchman himself who produced the list of doctors who would study abroad on a fellowship. See Rajchman to Doxiadis, May 15, 1929. Doxiadis Papers, folder 11. 


\section{The involvement of the Rockefeller Foundation and the campaign against malaria}

The Greek government attempted to ensure the collaboration of the R.F. through the intervention of the League of Nations in order to secure technical support and further overseas training for staff. It was not the first time for such a request; in 1923, the Greek government requested the R.F.'s technical and scientific assistance; however, the venture was not successful and the reasons are difficult to pin-point ${ }^{36}$. Besides, an attempt by Doxiadis in spring 1929, through the Greek ambassador in Washington, to make two R.F. fellowships available to Greek doctors did not bear any results ${ }^{37}$. However, an intervention by Madsen and Rajchman and the fact that the L.N.H.O. had already conducted research played an important part in the R.F.s acceptance of the Greek government's appeal for technical assistance and fellowships. In August 1929, the International Health Division (henceforth I.H.D.) of the R.F. accepted Rajchman's request to participate in the Greek reform campaign: «to dispatch R.F. specialists to Greece to oversee the reform, to provide partial funding for the projects it would agree to participate in, to make its fellowship programme available to Greek professionals and to engage personnel in the fieldwork throughout the joint effort» ${ }^{38}$.

Once it became clear that the L.N.H.O. would limit itself to the role of advisory agent, in December 1929, the Greek government, the League of Nations and the R.F. signed an agreement. The immediate goals of the collaboration focused on the eradication of malaria and the creation of modern agencies to head the state-controlled public health system.

During the following months and up to the spring of 1930, when R.F. commissioners arrived in Greece, a series of bills were passed with regard to the implementation of the League of Nations health programme. These

36. Giannuli, Dimitra. 'Repeated disappointment': The Rockefeller Foundation and the reform of the Greek public health system, 1929-1940. Bulletin of the History of Medicine. 1998; 7 (1): 47-72.

37. G. Vincent informed the Greek ambassador in Washington that the R.F. could not offer any fellowships while the League of Nations was still at work in Greece. However, he did not exclude to offer them in case of collaboration with the Greek government. Vincent to Simopoulos, 16 April 1929. Doxiadis Papers, folder 11.

38. For a detailed account of the R.F. mission to Greece see Giannuli, n. 36, p. 55. 
bills set out the establishment of the School of Hygiene ${ }^{39}$ and the Athens Hygiene Centre ${ }^{40}$, the establishment of the School of Social Hygiene visiting nurses ${ }^{41}$ as a branch of the School of Hygiene, that Home Office health services would be transferred to the Under-Secretariat of Hygiene ${ }^{42}$, and that R.S.C. dispensaries would come under the authority of the Ministry of Health ${ }^{43}$. The first round of institutional changes concluded in June 1929, when an autonomous Ministry of Health was established. Moreover, the cities and counties where the L.N.H.O. health programme would be implemented were selected ${ }^{44}$, while the health centres organised by Andrija Stampar in South Yugoslavia served as a model for the conversion of the rural R.S.C. dispensaries into state-run health centres ${ }^{45}$.

During the same period the L.N.H.O. appointed directors for the divisions: F. Norman White became Director of Hygiene and Preventive Medicine and director of the School of Hygiene; Marshal Balfour became Director of the division of Malariology; and Daniel E. Wright became Director of the division of Sanitary Engineering. Their tenure of office was five years and the R.F. would shoulder their salaries for the last two years and cover their travel expenses. Greek directors were appointed to the rest of the

39. Law No. 4069, Official Journal of 6 March 1929.

40. Law No. 4333, Official Journal of 17 August 1929.

41. Decree January 22, 1930.

42. Law, No. 4333. However, only the Home Office municipal health services were put under the supervision of the Ministry of Hygiene.

43. Law No. 4735, 16 May 1930.

44. During the first stage of implementation the counties of Corfu, Arta, Alexandroupolis and Chania were selected and during the second stage those of Attica, Salonica, Drama and Chania. The cities selected were Athens, Salonica and Piraeus.

45. In general, the Yugoslavian health system stood as a model to the Greek case. At Stampar's initiative, the first medical officers of the prefectures of Greek Macedonia, who were dispatched abroad, visited neighbouring Serbian Macedonia. Rajchman to Doxiadis, 16 May 1929. Doxiadis Papers, folder 9. The idea of sending Greek medical officers abroad for further training existed before the arrival of experts in Greece. Doxiadis to Metallinos, director of the Refugee Settlement Office in Macedonia, 20 October 1928; the former suggested that doctors at R.S.C. dispensaries be sent to Serbia to attend sanitation work in the field, Doxiadis Papers, folder 1. In addition, in 1931 Al. Pallis, Secretary General of the Ministry of Hygiene, visited Yugoslavia and admired the way public health was organised. Efimeris ton sizitiseon tis Voulis, 4th period; Session A, 1933-1934, p. 626-645. Al. Pallis. The social hygiene in Yugoslavia. Elefthero Vima (newspaper). 15 October 1930. See chapters by Dugac and by Zylberman in: Borowy; Gruner, n. 5, p. 277-304; 305-343. 
divisions ${ }^{46}$. Directors of all divisions were expected to teach the subjects of their respective expertise to medical students, social workers and school teachers at the School of Hygiene. A year later, the School of visiting nurses became operational as a branch of the School of Hygiene.

The R.F. involvement in Greece is similar to analogous endeavours of health organisation in other countries over the same period; the R.F. representatives held the view that eradicating malaria, training doctors, nurses and health administrators, and developing laboratories would encourage the medical profession to adopt «the new science of public health» and American methods of health administration ${ }^{47}$.

The most important tasks undertaken by the R.F. in Greece were the anti-malaria campaign and the operation of the School of Hygiene. Upon their arrival in Greece, Balfour and Wright founded the anti-malaria Committee at the Ministry of Hygiene which would coordinate the anti-malaria campaign ${ }^{48}$. They worked jointly with the N.E.F. and set up survey teams, which studied standards of living, climate conditions, the drinking water supply and sewage disposal system, and accumulated evidence with regard to malaria. The two organisations collaborated and exchanged both ideas and personnel. Graduates from the School of Hygiene were dispatched to Macedonia to practice, while N.E.F. staff attended courses at the School of Hygiene.

The R.F. funded the operation of a malaria laboratory at the School of Hygiene, a field laboratory in Salonica and five field stations, where students of the School of Hygiene and officers of the Ministry of Hygiene practiced. The collaboration of the R.F. with the Ministry of Hygiene and the Sanitary Department of the N.E.F. bore results; these areas saw improvements -the rate of those affected by malaria saw a sharp decrease in the middle 1930sand peasants were also trained in the self-help principle.

In 1933, 69 towns and villages were selected for a year's field research. In these areas, groups of skilled technicians demonstrated how to use means for the destruction of larvae and adult mosquitoes. N. Wright himself taught

\footnotetext{
46. The terms of the cooperation between R.F. and the Greek government in G.K.Strode to Eleftherios Venizelos, letter, 7 March 1930. Venizelos, E. Papers, box 135, folder 173, Ministry of Social Welfare, Historical Archives, Benaki Museum.

47. For the scientific and technical intervention of the R.F. in Europe see Löwy; Zylberman, n. 3, p. 3.

48. Makridis, n. 6, p. 78; Kopanaris, n. 13, p. 413-415.
} 
practical methods of rural sanitation to N.E.F. and R.F. staff in selected areas, mainly in Macedonia. Staff took sanitation courses at the School of Hygiene in Athens, in cooperation with the R.F., and later returned to their designated rural communities to teach methods of improving living conditions. Teams of trained individuals helped villagers install public latrines, drain small swamps and stagnant water, cover open ditches and repair the water supply system. They also made efforts to disseminate sanitation methods by organising lectures for teachers in rural areas. The intervention of the R.F. and the N.E.F. contributed to the preparation of local experts and the cooperation between the R.F., the School of Hygiene and the Ministry of Hygiene contributed to the preparation of the first public health officers including supervisors, doctors and social workers, skilled both in practical and theoretical terms. In 1932, two more American experts in malaria were added to the team.

In addition, the I.H.D. made a number of fellowships available for field studies in malaria. From 1930 to 1938, 11 doctors, 5 engineers and 6 nurses, a total of 22 individuals, studied on a scholarship either to Europe or America with the proviso that upon their return to Greece they would assist the American specialists ${ }^{49}$. The L.N.H.O. offered a number of fellowships to Greek medical officers to study health administration and epidemiology abroad. Moreover, the N.E.F. funded the studies of two Greek agronomists - who would be employed in the sanitation department of the organisation - at American universities.

\section{The accomplishments of the involvement of international health organisations}

The anti-malaria campaign, the fellowship programme and the training of a corps of experts at the School of Hygiene were the most important accomplishments of the R.F. mission to Greece. In contrast, the establishment of four peripheral health centres expected to decentralise public health services did not bear the intended results; the centres ran only for a year. Likewise, the School of Public Health Nursing did not last long. In

49. «Educational mission in Europe and America», Venizelos, E. Papers, box 135, folder 173, Ministry of Social Welfare, Historical Archives, Benaki Museum. 
December 1932, both the health centres and the School of Public Health Nursing were abolished because of governmental changes that led to an extended political crisis, which lasted for some years.

Although the anti-malaria field studies and the demonstration stations met with success in the areas where they were implemented, the government did not apply the anti-malaria measures on a national scale; it did not supply the required funds. Nikolaos Makridis, a doctor from Constantinople and high rank officer at the Ministry of Hygiene, who was sent to several European capitals in the early 1930s to study modern methods of social hygiene, gave a sobering account of the dualism of the anti-malaria campaign: namely, the coexistence of Greek officials at the Ministry of Hygiene and foreign experts of the Hygiene Centre ${ }^{50}$. No matter how hard did the Minister of Hygiene, Alexander Pappas, try, he was not successful in reconciling the two opposing parties which continued to disparage each other. Attempts by the Health Centre to reform the public health services in accordance with the League of Nations' programme were dismissed by the central service of the Ministry, according to Makridis, as «unnecessary and detrimental». Likewise, Ministry officials were accused of incompetence and professional inefficiency by the foreign experts. As a consequence of this bitter rivalry, but also because of the «quinine scandal», the Ministry's anti-malaria service was abolished at the end of 1933. In 1934, Norman White, Director of the School disappointed with the continuous political intervention and the financial constraints the government had to face, left Greece $^{51}$. In any case, starting in 1933 onwards, the funds channelled by the R.F. for the reform of public health organisation had gradually fallen off.

According to Dimitra Giannuli, the reasons for the unsuccessful R.F. intervention cannot be pinned on the bad cooperation between Greek and American experts, as was the case in other countries, but to the ubiquitous bureaucracy, political favouritism, nepotism and corruption of the public sector. Political intervention and political rivalry rendered the planning of public health policy by technocrats, and all the more so by foreigners, a difficult enterprise.

Although legislative acts passed in 1929 set out the administrative decentralisation of health services, they were never enforced and as a result

50. For a vivid description of the climate in the Ministry of Hygiene between 1929 and 1933 see Makridis, n. 6, p. 78-82.

51. Giannuli, n. 36. 
the integration of health services in the Ministry of Hygiene never took place. In addition, although the operation of peripheral health centres was legislated, these never commenced operations and although appropriate funds were set aside in the budget, they were never appropriated for the operation of public health services. Unfortunately, persistent attempts by the Venizelos government between 1928 and 1932 to institute social hygiene did not bear the intended results. An exception happened at the domain of child health ${ }^{52}$.

\section{Concluding remarks: what caused the plan to fail}

No matter how ambitious the Liberal Party plan for health reform had been, its electoral defeat in 1932 signalled the end of sanitary reform. The newly elected government, representing the Conservative Party, attempted to abolish many of the public health services already established, and to reorganise the public health system. One of its innovations concerned the reorganisation of the peripheral health services. The parliamentary debate on the peripheral health centres in December 1933 brought to light not only the public health problems which still persisted, but also the outdated views on public health. The views held by members of the Greek Parliament could be summarised as follows:

a. Malaria remained the most important health problem in the Greek countryside.

b. The lack of satisfactory hospital treatment and the absence of a social insurance system ${ }^{53}$ rendered any reform of the public health field ineffective.

c. The emphasis of the health reform should be placed on therapeutic and not on preventive medicine, the latter deemed a luxury for Greece.

52. Karakatsani, Despina; Theodorou, Vassiliki. Les hygiénistes à l'école: soins et prophylaxie, s'agissant de la santé des enfants d'âge scolaire, en Grèce, au début du 20ième siècle. In: JacovidesAndrieu, Anna Olvia, ed. Le corps dans la langue, la Littérature, l'Histoire, les Arts et les Ars du spectacle [Actes du XVIIle Colloque Internationale des Néo-hellénistes des Universités francophones 15-17 Mai 2003]. Paris: Société Culturelle Néo-Hellénique; 2005, p. 55-69.

53. Laws providing for the establishment of a social insurance system in Greece passed a few months later. 
d. The Hygiene Centre and the School of Hygiene were regarded as unsuccessful enterprises on which excessive funds had been wasted ${ }^{54}$. The School of Hygiene on which 80 million drachmas were squandered, only managed to place at the state's disposal approximately 40 to 42 hygienists and 20 to 22 nurses.

e. The health reform attempted by the League of Nations did not come to fruition because, despite the funds allotted, it failed to change the health conditions for rural populations.

f. The R.F.s most important goal, namely preparing public health officials such as visiting nurses and hygienists, was even beyond the grasp of those Members of Parliament who were doctors themselves.

Cutbacks in expenditure for the needs of public health -in 1934 the Committee's plan allotted 77 millions drachmas to public health; however, in the event, only 9 millions were finally spent- were an indication of the intentions of the newly elected government.

The reasons for the failure of the L.N.H.O. programme can be pinpointed at many levels. Overall, we could identify three major reasons. The first was economic: after the deterioration of the country's finances at the beginning of 1930, there were insufficient funds available. The international economic crisis was felt in Greece in 1932, making it impossible for the government to pay off the foreign debt as well as to guarantee new loans; hence, bankruptcy was inevitable.

The second reason can be pinned down to political upheaval at that time. The two opposing political forces (the Liberal and the Conservative Parties) regularly replaced one another in government in an atmosphere of political confrontation. The government of the Liberal Party (1928-1932) was forced to resign in May 1932. The following year witnessed repetitive elections and attempts at coups d'état. The implementation of the League of Nations programme failed in the midst of political disputes between the Liberal and the Conservative Party, which influenced public health policy. The latter having won the 1933 elections, after a long time, called

54. Many parliamentary members argued that the health problems placed health «in the hands of health schools, supervisors and visiting nurses, while debarring its natural protectors, the doctors». See, Efimeris ton Sizitiseon tis Voulis. 1933-1934. 4th Period; Session A, p. 626-643. 
off implementation of the health restructuring program, describing it as costly and inapplicable.

Finally, the third reason was restrictedly professional; both the political leaders of the Health Ministry and the Medical Association were against the Committee proposals. The major reaction came from a part of the medical corps that declared a war against the L.N.H.O. mission. The Hellenic medical community was quick to criticise the foreign health experts' suggestions. Their criticism was levelled at the decision to establish a School of Hygiene as well as at the excessive funding required by the Ministry of Hygiene. The Medical Association also disapproved of the high remuneration of the Committee's members while the fact that the Greek government sought help in foreign expertise offended the Greek doctors' national pride ${ }^{55}$. The above objections were well recorded in the contemporary medical press ${ }^{56}$.

As Doxiadis had already foreseen, the administrative integration of health services was not achieved due to political intervention and bureaucratic inertia. The lack of collaboration with the local bureaucracy was not particular to the Greek case. Yet, it was only in Greece that this lack of understanding went as far as to cancel this promising venture. The social security program, finally implemented in 1934, was the only institution that survived.

In the history of international interventions during the Interwar period, the Greek case provides a good example for diversity.

55. The same attitude of mistrust can be detected towards the R.F. Mission under Balfour's guidance which was sent to Greece during the same period in order to organize the anti-malaria fight. Makridis, n. 6, p. 82-83.

56. Eleptheriades, D. The Health Committee. Public hygiene. 1931; 6: 124-129; Elephteriades, D. The budget of the Ministry of hygiene. Public Hygiene. 1931; 8: 234-256; Estia (newspaper),15 September 1931; The Committee of Hygienists raiding the meagre State Revenue Office. Public Hygiene. 1931; 9: 377. 